九州大学学術情報リポジトリ

Kyushu University Institutional Repository

\title{
Functional Morphology of the Type III Acini of the Salivary Gland in the Male Cattle Tick, Haemaphysalis Longicornis
}

Yanagawa, Hisashi

Zoological Laboratory, Faculty of Agriculture, Kyushu University

Mori, Takayuki

Zoological Laboratory, Faculty of Agriculture, Kyushu University

Shiraishi, Satoshi

Zoological Laboratory, Faculty of Agriculture, Kyushu University

Uchida, Teruaki

Zoological Laboratory, Faculty of Agriculture, Kyushu University

https://doi.org/10.5109/23915

出版情報: 九州大学大学院農学研究院紀要. 33 (1/2)，pp.37-45，1988-10. Kyushu University バージョン：

権利関係 : 


\title{
Functional Morphology of the Type III Acini of the Salivary Gland in the Male Cattle Tick, Haemaphysalis longicornis*
}

\author{
Hisashi Yanagawa ${ }^{\dagger}$, Takayuki Mōri, Satoshi Shiraishi \\ and Teru Aki Uchida
}

Zoological Laboratory, Faculty of Agriculture, Kyushu University 46-06, Fukuoka 812, Japan.

(Received March 18, 1988)

\begin{abstract}
The present study elucidated the ultrastructural changes of Type III acini of the salivary gland in the male cattle tick, Haemaphysalis longicomis, during feeding. Type III acini comprised five kinds of cells: the c- and d-cells, both of which are granule-containing cells, and the e-cell, the abluminal interstitial cell and adluminal interstitial cell, all of which are agranular cells. Both the c-cell and the d-cell which appear to secrete attachment cement precursors, exhibited a high secretory activity throughout the feeding period. This finding accorded well with the fact that the male tick repeats attachment and feeding, and needs to secrete attachment cement during the feeding cycle. The agranular cells changed their structure after attachment to a considerable extent : both the transformed e-cell and the abluminal interstitial cell had extensive infoldings of the basal plasma membrane characteristic of fluid-transporting epithelia. In contrast to the above two kinds of cells in the female, which requires a large volume of blood meal, these cells in the male did not increase much in volume. Such poor development of the agranular cells in the male tick during feeding paralleled the much lower fluid excretory activities of the male salivary gland.
\end{abstract}

\section{INTRODUCTION}

The importance of the ixodid tick salivary glands in the transmission of harmful toxins and pathogens (e. g. Theileria and Babesia protozoa) to livestock is well known. Therefore, in many ticks, the histological, histochemical and ultrastructural studies of the salivary gland have been extensive (Binnington and Kemp, 1980 ; Kemp et al., 1982). However, the main object of these morphological studies has been concerned with the female salivary gland, and the male salivary gland has been studied only in passing. The salivary gland of male ticks has been examined histologically and/or histochemically for Rhipicephalus appendiculatus (Till, 1959, 1961), H aemaphysalis spinigera (Chinery, 1965), Hyalomma asiaticum (Balashov, 1972), and Boophilus microplus (Binnington, 1978), and ultrastructurally for Dermacentor variabilis (Coons and Roshdy, 1973) and R.appendiculatus (Walker et al., 1985).

The knowledge on the functional morphology of the salivary gland in the female cattle tick, Haemaphysalis longicornis (Yanagawa et al., 1987) has revealed that the Type III acini play an important role in secretion of attachment cement and in

\footnotetext{
*Reprint requests to the third author.

†Present address : Laboratory of Wildlife Resource Ecology, Obihiro University of Agriculture and Veterinary Medicine, Obihiro 080
} 
elimination of excess water and electrolytes. In the male cattle tick, however, there has been no morphological study on the salivary gland. The feeding pattern of the male tick differs conspicuously from that of female. Thus, the aim of this study is to examine with the light and electron microscope the structure of Type III acini in unfed and feeding males, and to discuss the functional morphology of the acini with special emphasis on the difference between both sexes.

\section{MATERIALS AND METHODS}

Male ticks of H. Zongicornis were collected by the flagging method on the pastures in the Kujū highland, Oita Prefecture. These males were fed together with some females on the ears of rabbits under laboratory conditions.

Salivary glands were dissected from live ticks immersed in a cold $1.5 \%$ glutaraldehyde in $0.1 \mathrm{M}$ cacodylate buffer ( $\mathrm{pH} 7.4$ ), fixed with the same fixative, and subsequently washed in the same buffer ; the tissues were post-fixed with $1 \%$ osmium tetroxide in the same buffer, dehydrated with aceton and embedded in epoxy resin. Thin sections (ca. $60 \mathrm{~nm}$ ) for electron microscopy were cut on a Porter-Blum MT-1 microtome, and doubly stained with ulanyl and lead citrate and examined in an Hitachi HS-9 electron microscope $(75 \mathrm{kV})$. Thick sections (ca. $1.5 \mu \mathrm{m})$ for light microscopy were stained with toluidine blue.

\section{Unfed stage}

\section{RESULTS}

Type III acini of unfed male H. Zongicornis, measure ca. $50 \times 60 \mu \mathrm{m}$ in size. The cells which comprise the acini can be broadly divided into two sorts, i. e. large granule-containing cells and smaller agranular cells. At this stage, two kinds of granule-containing cells (the c- and d-cells) occupy the major portion of the acinar volume, and a group of agranular cells recognized only at the acinar fundus make up a small portion of the acini (Fig. la).

The c-cells situate adjacent to the opening of the acinus, whose granules stain deep blue with toluidine blue (Fig. la) ; these granules are of a turtleback structure consisting ultrastructurally of large electron-lucent subunits which occasionally contain an electron dense core (Fig. 2a). The large d-cells occupy an intermediate position between the c-cells and the agranular cells. The cytoplasm of the d-cell is filled with large spherical or ovoid granules that stain less intensely with toluidine blue than those of the c-cell (Fig. la); the electron-opaque granules are composed of closely packed fine honeycomb subunits (Fig. 2b). The c- and d-cells are abundant in well-developed rough endoplasmic reticulum ( $\mathrm{rER}$ ) and mitochondria, and have already exhibited a high secretory activity (Fig. 2a, b).

By electron microscopy, a group of agranular cells comprise three kinds of cells, i. e. the e-cell, the adluminal interstitial cell and the abluminal interstitial cell (Fig. 2c). The e-cells alternate with the adluminal interstitial cells around the lumen and are firmly attached to them by juxtaluminal zonulae adherentes and extensive septate desmosomes. The apical plasma membranes of these cells have short microvilli. The e-cell is relatively large among the three kinds of agranular cells and possesses a large 

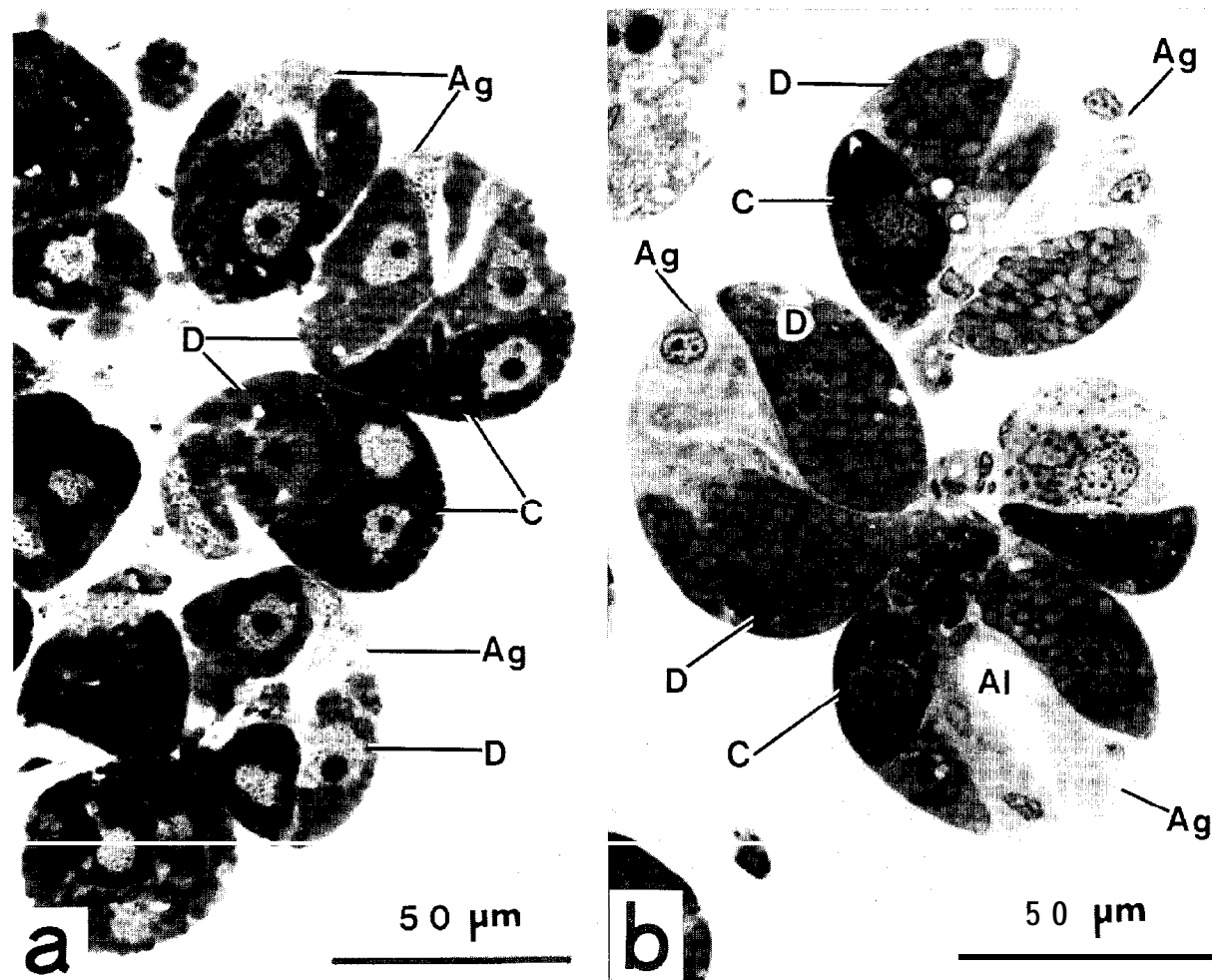

Fig. 1. Light micrographs showing Type III acini of the salivary gland in the male H. longicornis. The granules of the c- and d-cells stain deep blue and light blue with toluidine blue respectively. a) Unfed stage. Some small agranular cells are confined in the most basal region of the acinar fundus. b) Feeding stage (five-day phase after attachment). The agranular cells develop considerably, and come to occupy the major portion of the acinar fundus. The following abbreviation are used in Figs. 1-3 : Abi, abluminal interstitial cell ; Adi, adluminal interstitial cell ; Ag, agranular cell ; $\mathrm{Al}$, acinar lumen ; Bm, basement membrane ; C, c-cell ; $\mathrm{Cg}$, c-cell granule ; D, d-cell ; Dg, d-cell granule ; E, e-cell ; G, granule ; H, haemolymph ; M, mitochondrion; Mt, microtubule ; Mv, microvilli ; $\mathrm{N}$, nucleus ; R, rough endoplasmic reticulum; Sd, septate desmosome ; V, vacuole ; Za, zonula adherense.

nucleus, some mitochondria, a little rER, a few small vacuoles and occasionally a few small granules with a high electron-density. The adluminal interstitial cell whose cytoplasm is sparse contains a few mitochondria and some microtubles. The abluminal interstitial cell found in the most peripheral region of the acinar fundus, possesses a relatively large nucleus and scanty cytoplasm with only a few mitochondria (Fig. 2c).

\section{Feeding stage}

Type III acini expand their acinar lumina and somewhat enlarge to ca. 70 x $80 \mu \mathrm{m}$ in size ; the c- and d-cells maintain many granules and exhibit a high secretory activity 
throughout the feeding period; the e-cell and two types of interstitial cells increase considerably in their volume and occupy the major portion of the acinar fundus (Fig. lb).

Electron microscopically, at the basal region of the acinus, the e-cell and the abluminal interstitial cell exhibit an elaborate system of membraneous infoldings, and the abluminal interstitial cell in particular has undergone dramatic changes in structure and volume ; the cytoplasm of these basal labyrinth is filled up with numerous elongated mitochondria and free ribosomes (Fig. 3a). On the other hand, at the central region of the acinus, the e-cell possesses a number of vacuoles and some mitochondria ; the adluminal interstitial cell is rich in bundles of parallel microtubles (Fig. 3b).

Most of the agranular cells are active throughout the feeding period, but some of the e-cells show more vacuolated and degenerated appearance at the late stage of feeding (e. g. ten-day phase after attachment) (Fig. 3c).

\section{DISCUSSION}

The female cattle tick $\mathbf{H}$. longicornis requires a single attachment and feeding in order to obtain a large volume of blood. The male cattle tick, however, does not need the large quantity of blood meal, and repeats the attachment and feeding for copulation. From the results of the previous paper (Yanagawa et al., 1987), it has been suggested that the functions of Type III acini in the female cattle tick are secretion of attachment cement precursors, excess water elimination and ionic regulation. Type III acini of the male consisting of the same kinds of cells as those of the female, are discussed separately according to the following two categories from the viewpoint of the functional morphology.

\section{Functional morphology of the granule-containing cells}

All ixodid ticks, with the exception of some Prostriata (the genus Ixodes with a relatively long hypostome, e. g. I. holocyclus, I. pseudorasus and I.trianguliceps), utilize attachment cement so as to feed smoothly. In the Brevirostrata (the genus Dermacentor, Rhipicephalus, Boophilus and Haemaphysalis) of the Metastriata, the mouthparts are short and barely penetrate the host epidermis ; therefore, an external supporting cement cone is produced to secure tick attachment (Kemp et al., 1982). Histological and histochemical studies on the salivary gland in Haemaphysalis spinigera (Chinery, 1965), Boophilus microplus (Binnington, 1978) and Rhipicephalus appendiculatus (Walker et al., 1985) have revealed that the granule-containing cells of Type III acini contribute to secretion of attachment cement precursors. Furthermore, Chinery (1973) has indicated that attachment cement of H. spinigera is derived from precursors in the a-cell of Type II acini and the c-cell of Type III acini (external cement), and in

Fig. 2. Electron micrographs of Type III acini in the unfed male H.longicornis. a) The c-cell granules with a turtleback structure. b) The d-cell granule consisting of fine honeycomb subunits. c) A group of inactive cells at the acinar fundus. The relatively large e-cells alternate with the small adluminal interstitial cells around the acinar lumen. A small abluminal interstitial cell with a relatively large nucleus and scanty cytoplasm is recognized at the most peripheral region. Abbreviations : see the legend to Fig. 1. 

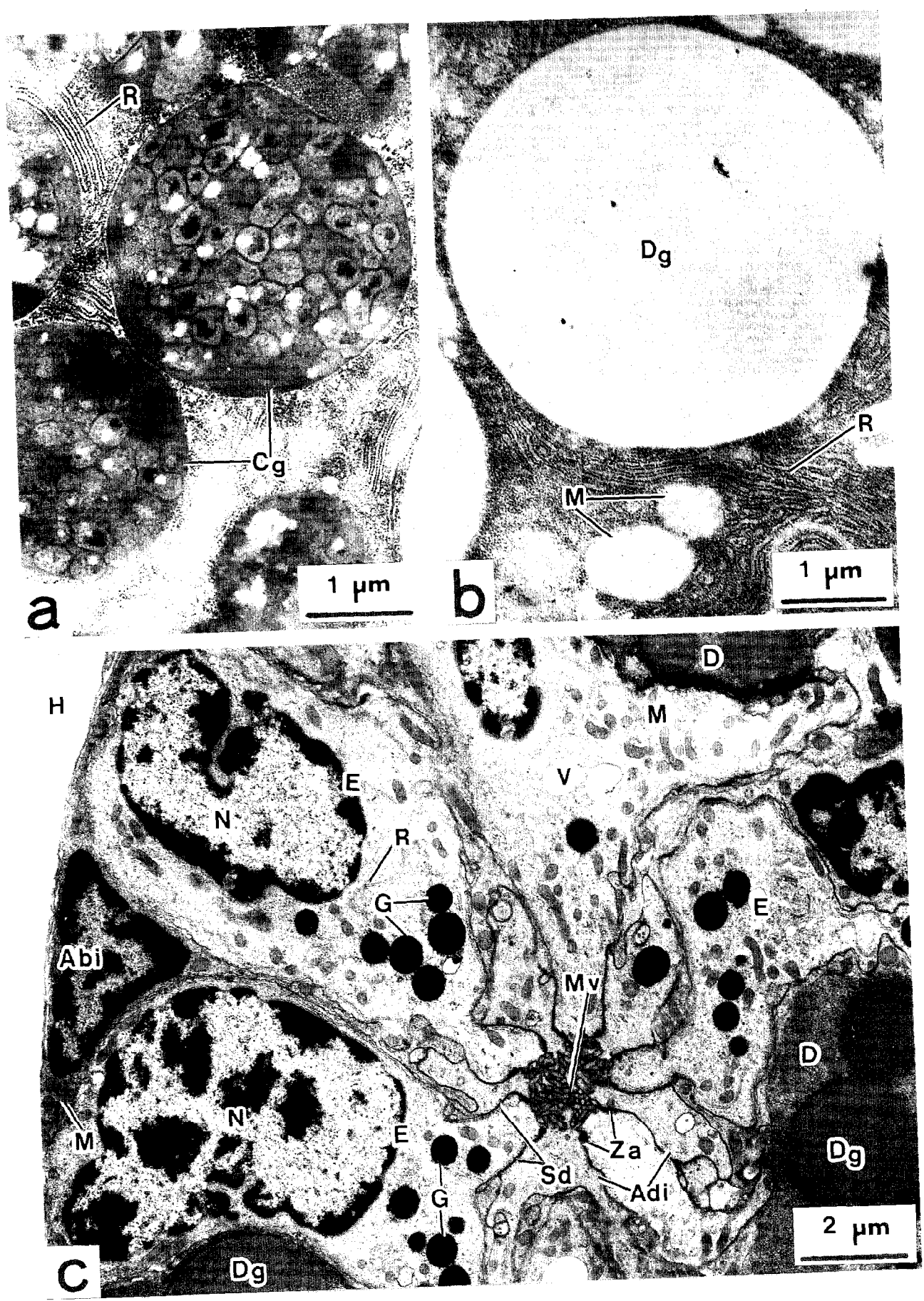
the d-cell of Type III acini (internal cement).

The structure of the c- and d-cells of Type III acini in the male H. Zongicornis, bore a close parallel to their sister cells in other ixodids, which are most likely candidates for secretion of attachment cement precursors ; histologically, the c- and d-cells in $\mathbf{H}$. Zongicornis correspond to the c- and d-cells in both R. appendiculatus (Till, 1959, 1961) and H. spinigera (Chinery, 1965, 1973), and the d- and e-cells in B.microplus (Binnington, 1978), respectively ; ultrastructurally, each granule of the c- and d-cell in $H$. Zongicornis is composed of large and fine subunits, as well as the above sister cells in B.microplus (Megaw and Beadle, 1979) and R. appendiculatus (Fawcett et al., 1981a; Walker et al., 1985). Thus, it is assumed that the c- and d-cells of Type III acini in the male H. Zongicornis are closely related to secretion of attachment cement precursors.

Also in the female $\mathbf{H}$. Zongicornis, the c- and d-cells of Type III acini are thought to secrete the cement (Yanagawa et al., 1987). There were no structural differences in the c- and d-cells between both sexes. However, the sequential changes of the c- and d-cells in the male tick during feeding were different considerably from those in the female. In the female tick, the c- and d-cells of Type III acini exhibit a conspicuous secretory activity just after attachment, and then begin to shrivel at the early stage of feeding (Yanagawa et al., 1987) : in the male tick, to the contrary, the c- and d-cells retained many granules and showed a constant high secretory activity during feeding, even in the five- or ten-day phase after attachment. This difference of cellular changes is probably due to the disparity of the feeding pattern between the male and female, as mentioned above. The male tick repeats the attachment and feeding frequently, in contrast to the female which requires only one attachment and feeding. Therefore, the male tick needs to secrete attachment cement repeatedly, and to continue the high secretory activity of the c- and d-cells of Type III acini throughout the feeding period.

\section{Functional morphology of the agranular cells}

The feeding of bloodsucking arthropods is accompanied by the elimination of excess water and electrolytes resulted from the concentration of the blood meal. The water and ions may be rapidly eliminated during, or after feeding, by the Malpighian tubules in bloodsucking insects, or by the coxal organ in argasid ticks. Since physiological studies on B.microplus (Tatchell, 1967, 1969), it has been suggested that the excess water and electrolytes are returned to the host by means of salivary secretion, and in H. Zongicornis also, the salivary gland plays physiologically important roles in osmotic and ionic regulation (Kitaoka and Morii, 1970 ; Kitaoka, 1971).

Many histological studies on the salivary gland in ixodids have demonstrated that the agranular cells of Type III acini undergo remarkable changes during feeding (Till, 1961 for R. appendiculatus; Chinery, 1965 for H. spinigera; Balashov, 1972 for Ixodes ricinus and H. asiaticum ; Binnington, 1978 for B.microplus; Binnington and Stone, 1981 for I.holocyclus, etc.). Moreover, an addition to the recent ultrastructural

Fig. 3. Electron micrographs of Type III acini in the feeding male H. longicornis. a) An active abluminal interstitial cell with extensive infoldings of the basal plasma membrane (five-day phase after attachment). b) The transformed e-cells containing some vacuoles and the adluminal interstitial cells with many microtubules (five-day phase after attachment). c) A degenerating e-cell (ten-day phase after attachment). Abbreviations: see the legend to Fig. 1. 

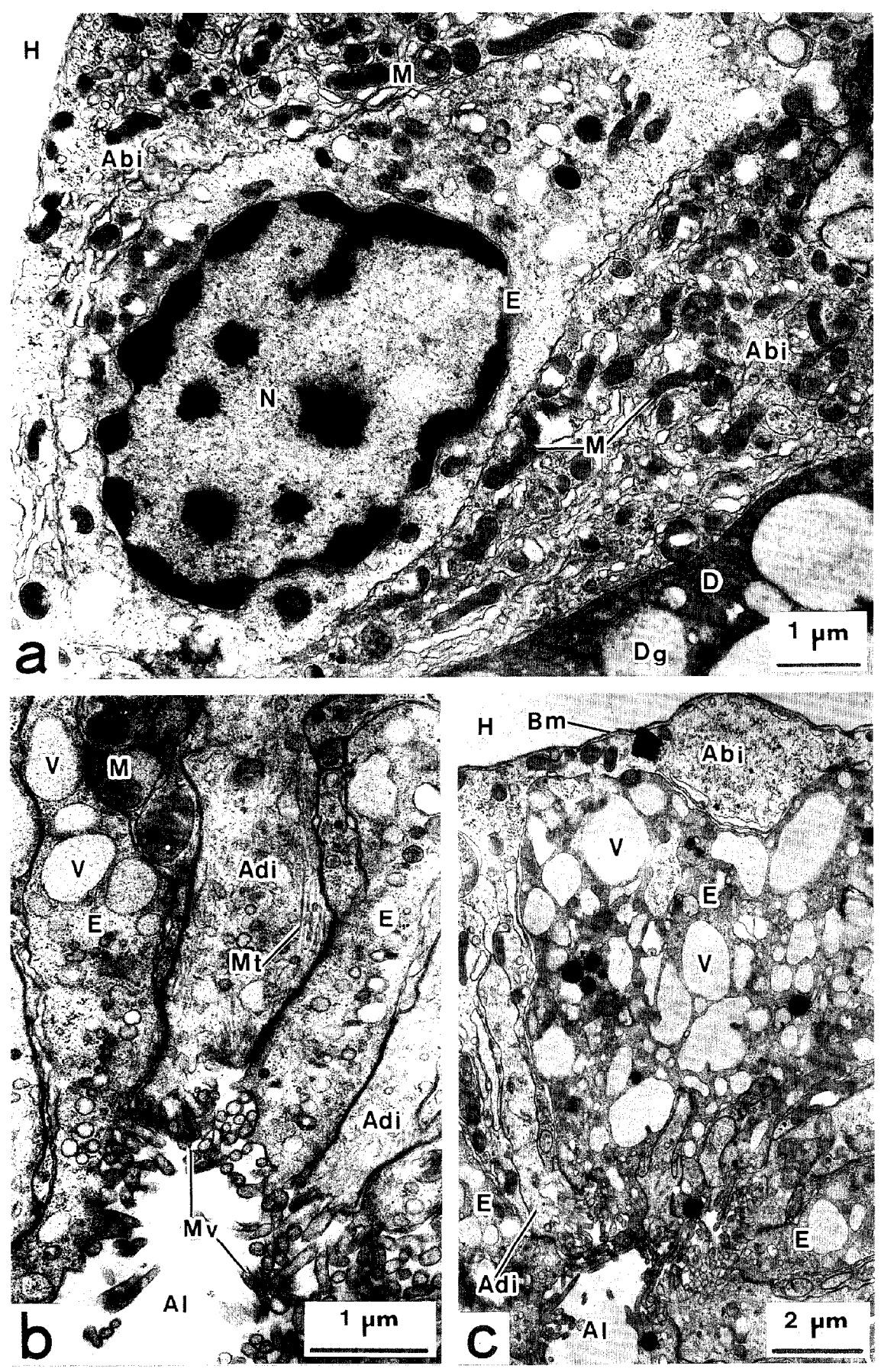
knowledge has indicated that one or two kinds of the agranular cells, which show extensive infoldings of the basal plasma membrane, play a significant role in the elimination of the excess water and electrolytes (Kaufman and Sauer, 1982).

In feeding $D$. andersoni (Meredith and Kaufman, 1973) and B.microplus (Megaw and Beadle, 1979), three types of agranular cells, i. e. the vacuolar cell, water cell and cap cell (corresponding to the e-cell, abluminal interstitial cell and adluminal interstitial cell in $H$. Zongicornis, respectively) have been observed ; the water cell which has an elaborate system of membranous infoldings is thought to have a fluid excretory role. Similarly, three types of the agranular cells, i. e. the transformed f-cell (the e-cell in H. Zongicornis), abluminal interstitial cell and adluminal interstitial cell have been found in Type III acini of feeding R.appendiculatus (Fawcett et al., 1981a, b) ; in $R$. appendiculatus, both the transformed f-cell and the abluminal interstitial cell have borne a basal labyrinth characteristic of fluid-transporting epithelia. Moreover, Balashov (1983) has described the epithelial cell in Type III acini of H. asiaticum, which seems to take the same role as the water cell in $D$. andersoni (Meredith and Kaufmann, 1973).

In the male $\mathbf{H}$. Zongicornis also, there were three types of the agranular cells in Type III acini ; both the e-cell and the abluminal interstitial cell exhibiting an elaborate system of membranous infoldings, are thought to function in maintaining osmotic and ionic balance ; and the remaining pillar-like adluminal interstitial cell, which had no obvious structural specialization except for numerous microtubules, appears to play a role in supporting the former two kinds of cells.

During feeding, Type III acini in the female H. Zongicornis enlarge from ca. $50 \mathrm{x}$ $50 \mu \mathrm{m}$ to ca. $90 \times 110 \mu \mathrm{m}$, cheifly owing to expansion of the transformed e-cells and abluminal interstitial cells (Yanagawa et al., 1987). In contrast to the female $\mathbf{H}$. Zongicornis, however, the e-cell and abluminal interstitial cell in the male increased slightly in volume. Therefore, Type III acini of the male did not much develop (ca. $70 \mathrm{X}$ $80 \mu \mathrm{m}$ in size). The poor development of the agranular cells in male Type III acini has been observed also in several other ixodid ticks, i. e. H. spinigera (Chinery, 1965), H. asiaticurn (Balashov, 1972), Amblyomma hebraeum (Sauer, 1977), B. microplus (Binnington, 1978), R. appendiculatus (Walker et al., 1985), etc. Such phenomena adduce evidence for the much lower fluid secretory activities of the male salivary gland. Thus, it is concluded that the difference in the developmental degree of the agranular cells between the male and the female is attributed to the difference of the blood meal requirements between both sexes from the standpoint of the functional morphology.

\section{ACKNOWLEDGEMENTS}

We wish to express our heartfelt thanks to the staff of Kujū Agricultural Research Center of Kyushu University for their kind help in collecting ticks, and to Professor E. W. Jameson, Jr., University of California for comments on the manuscript. This work was supported in part by a Grant-in-Aid from the Ministry of Education, Science and Culture, Japan (No. 62560269).

\section{REFERENCES}

Balashov, Yu. S. 1972 Bloodsucking ticks (Ixodoidea) — Vectors of diseases of man and animals. 
Transl. by 0. G. Strekalovsky, Misc, Publ. ent. Soc. Am., $8: 161-376$

Balashov, Yu. S. 1983 An atlas of ixodid tick ultrastructure. Transl. by A. S. Raikhel, Special Publ. ent. Soc. Am.

Binnington, K. C. 1978 Sequential changes in salivary gland structure during attachment and feeding of the cattle tick, Boophilus microplus. Int.J.Parasit., $8: 97-115$

Binnington, K. C. and D. H. Kemp 1980 Role of tick salivary glands in feeding and disease transmission. Adv. Parasit., 18: 315-339

Binnington, K. C. and B. F. Stone 1981 Developmental changes in morphology and toxin content of the salivary gland of the Australian paralysis tick Ixodes holocyclus. Int. J. Parasit., 11: 343-351

Chinery, W. A. 1965 Studies on the various glands of the tick Haemaphysalis spinigera Neumann, 1897. Part 3. The salivary glands. Actatrop., $22: 321-349$

Chinery, W. A. 1973 The nature and origin of the 'cement' substance at the site of attachment and feeding of adult Haemaphysalis spinigera (Ixodidae). J. Med. Ent., 10:355-362

Coons, L. B. and M. A. Roshdy 1973 Fine structure of the salivary glands of unfed male Dermacentor variabilis (Say) (Ixodoidea : Ixodidae). J. Parasit., 59 : 900-912

Fawcett, D. W., S. Doxsey and G. Btischer 1981a Salivary gland of the tick vector (Rhipicephalus appendiculatus) of East Coast fever. 1. Ultrastructure of the type III acinus. Tissue Cell, $13: 209$ 230

Fawcett, D. W., S. Doxsey and G. Büscher 1981b Salivary gland of the tick vector (Rhipicephalus appendiculatus) of East Coast fever. 2. Cellular basis for fluid secretion in the type III acinus. Tissue Cell, 13: 231-253

Kaufman, W. R. and J. R. Sauer 1982 Ion and water balance in feeding ticks : mechanisms of tick excretion. In "Physiology of Ticks", ed. by F. D. Obenchain and R. Galun, Pergamon Press, Oxford, pp. 213-244

Kemp, D. H., B. F. Stone and K. C. Binnington 1982 Tick attachment and feeding : role of the mouthparts, feeding apparatus, salivary gland secretions and the host response. In "Physiology of Ticks", ed. by F. D. Obenchain and R. Galun, Pergamon Press, Oxford, pp. 119-168

Kitaoka, S. 1971 Chloride balance in feeding of ixodid and argasid ticks (Acari: Ixodoidea). Jap. J. appl. Ent. Zool., 15: 161-167 (In Japanese with English synopsis)

Kitaoka, S. and T. Morii 1970 Ionic and water balance in the feeding process of ixodid ticks. Natl Inst. Anim. Hlth Q., 10: 34-41

Megaw, M. W. J. and D. J. Beadle 1979 Structure and function of the salivary glands of the tick, Boophilus microplus Canestrini (Acarina: Ixodidae). Int. J. Insect Morph. Embryol., 8: 67-83

Meredith, J. and W. R. Kaufman 1973 A proposed site of fluid secretion in the salivary gland of the ixodid tick Dermacentor andersoni. Parasitology, 67 : 205-217

Sauer, J. R. 1977 Acarin salivary glands —- Physiological relationships. J. Med. Ent., 14 : $1-9$

Tatchell, R. J. 1967 Salivary secretion in the cattle tick as a means of water elimination. Nature, Lond., 213: 940-941

Tatchell, R. J. 1969 The ionic regulatory role of the salivary secretion of the cattle tick Boophilus microplus. J. Insect Physiol., $15: 1421-1430$

Till, W. M. 1959 New cell types in the salivary glands of the brown ear tick, Rhipicephalus appendiculatus Neumann. Nature, Lond., 184 : 1078-1079

Till, W. M. 1961 A contribution to the anatomy and histology of the brown ear tick Rhipicephalus appendiculatus Neumann. Mem. ent. Soc.S. Afr., (6) : 1-124

Walker, A. R., J. D. Fletcher and H. S. Gill 1985 Structural and histochemical changes in the salivary glands of Rhipicephalus appendiculatus during feeding. Int. J. Parasit., $15: 81-100$

Yanagawa, H., T. Mōri, S. Shiraishi and T. A. Uchida 1987 Ultrastructural changes in the salivary gland of the female cattle tick, Haemaphysalis longicomis, during feeding. J. Zool., Lond., 212 : 283-301 